\title{
Analysis of physico-chemical parameters: an empirical study of yewa river ogun and part of badagry creek lagos, Southwest Nigeria
}

\begin{abstract}
The water quality was analysed for physiochemical parameters to ensure safe and continuous consumption by the citizens of Yewa Ogun State and Badagry, Lagos State southwestern Nigeria. In view of this, a detailed physical and chemical analysis of water samples was carried out across Yewa River and part of Badagry Creek. The physiochemical parameters studied are; $\mathrm{pH}$, Salinity, EC, TDS, TS and TSS. Fifteen (15) samples each were taken across Yewa River and part of Badagry Creek making a total sample of thirty (30). Sterilized empty table bottle water was used to collect all the thirty (30) samples across the River and the Creek which was drawn from midstream at $0-10 \mathrm{~cm}$ depth below the surface of the water. Physiochemical analysis on all sampled water was carried out in the Laboratory. From the result of the Laboratory test carried out, the mean, minimum and maximum value of Hydrogen ion concentration $(\mathrm{pH})$, salinity (psu), Electrical conductivity (EC $\mu \mathrm{Scm}^{-1}$ ), total dissolved solid (TDS)mg/l, total solid and total suspended solid (TSS)mg/1 are (5.87, 5.35, 6.21), (0.499, 0.34, $0.65) \mathrm{psu},(970.40,520,1270) \mu \mathrm{Scm}^{-1},(485.20,260,635) \mathrm{mg} / \mathrm{l},(955.60,920,1115)$ $\mathrm{mg} / \mathrm{l},(470.40,340.5,815) \mathrm{mg} / \mathrm{l}$ for Yewa River and $(4.72,3.8,5.8),(0.46,0.28$, 0.79)psu, $(961,678,1574) \mu \mathrm{Scm}^{-1},(480.5,339,787) \mathrm{mg} / \mathrm{l},(982.62,625,1896) \mathrm{mg} / \mathrm{l}$, $(496.25,153,1109) \mathrm{mg} / \mathrm{l}$ for part of Badagry Creek. The Hydrogen ion concentration $(\mathrm{pH})$ for both study area were found to be lower than World Health Organization (WHO) recommended limit of 6.5-8.5 in all samples. The T-test correlation analysis was conducted for the parameter studied for the River and the Creek as well as the correlation between the River and the Creek. The result was presented in form of statistical table showing the correlation between the water sampled in Yewa River and across part of Badagry Creek and the correlation that exists between the River and the Creek using Eviews 9 statistics software package. It was concluded that Yewa and part of Badagry Creek was a good source of portable drinking water as both meet the WHO recommended limit.
\end{abstract}

Keywords: correlation, groundwater, laboratory, physiochemical parameters, test
Volume I Issue 7 - 2017

\author{
Adewuyi Gbola K,' Badejo Olusegun T,' \\ Idowu Funmilola F,' Ogunjobi Gregory A,' \\ Gbopa Adetola $\mathrm{O}^{\prime}$ \\ 'Department of Surveying and Geoinformatics, The Polytechnic \\ Ibadan, Nigeria \\ ${ }^{2}$ Department of Surveying and Geoinformatics, University of \\ Lagos Akoka, Nigeria
}

Correspondence: Adewuyi Gbola K, Department of Surveying and Geoinformatics, The Polytechnic Ibadan, Nigeria,

Email adewuyismart@yahoo.com

Received: December 08, 2017 | Published: December 21, 2017
Abbreviations: PH, Hydrogen Ion Concentrate; EC, Electrical Conductivity; TDS, Total Dissolved Solids; TSS, Total Suspended Solids; TS, Total Solids; ds/m, Decisiemen per Meter; WHO, World Health Organisation

\section{Introduction}

Surface and Ground water is important source of water supply in the world which is needed for human survival and industrial development. The ground and surface water chemistry is controlled by the composition of its recharge components as well as geological and hydrological variations within the aquifers. ${ }^{1}$ Khodapanah et $\mathrm{al}^{2}$ opined that polluted ground and surface water sources are the cause for the spread of epidemic and chronic disease in human beings. Industrialization and increase in population are responsible for depletion of our groundwater sources. Improved knowledge is required for understanding and evaluating the suitability of groundwater for different purposes. Groundwater quality comprises physical, chemical and biological qualities of groundwater. ${ }^{3} \mathrm{~A}$ measure of the quantity of dissolved salts and other minerals in sea water is the term salinity. Normally, salinity can be defined as the total amount of dissolved solids in sea water in parts per thousand (ppt or
$\%$ ) by weight. Generally, salinity cannot be determined directly but can be computed from chlorinity, electrical conductivity, refractive index or some other property whose relationship to salinity is well established. In the Law of Constancy of Proportions, sample salinity can be established by the level of chlorinity in a sea water sample. The average salinity of sea water is around $35 \%$. The rate of variation of sound velocity is approximately $1.3 \mathrm{~m} / \mathrm{s}$ for a $1 \%$ alteration in salinity. Water is an invaluable resource to man and living things, essential for the sustenance of life ${ }^{4}$ on earth as exemplified by its diversified uses (drinking, cooking, washing, irrigation, farming etc.). ${ }^{5}$ The quality of drinking water is a powerful environmental determinant of health. ${ }^{6}$ In a recent survey by, ${ }^{7}$ it is estimated that 65 million Nigerians had no access to safe drinking water. Many human communities around the world are increasingly turning to groundwater for their water needs. Groundwater is water that exists underground. ${ }^{8}$ It represents all the water present in the soils' voids and fissures within geological formations which come from natural precipitation either directly by infiltration or indirectly from rivers. ${ }^{9}$ Without safe water near dwellings, the health and livelihood of families can be severely affected. ${ }^{10,11}$ Concentrations of target substances in the groundwater increase or decrease along the flow path from the upstream to the downstream wells,${ }^{12}$ human activities may consequently pollute this water source 
overtime and make it unsafe for use without prior treatment. More so, several research findings ${ }^{6-13}$ have revealed a definite correlation between human socio-economic activities and industrialization to pollution patterns/trends of groundwater. Therefore, the evaluation of groundwater quantity and quality is essential for the development of civilization and to establish database for future water resources strategic planning and development. ${ }^{14}$ However, human activities can alter the natural composition of groundwater through mining activities, disposal or dissemination of chemicals and microbial matter at the land surface and into soils or through injection of wastes directly into groundwater. High values of TDS in ground water are generally not harmful to human beings but high concentration of these may affect persons who are suffering from kidney and heart diseases. ${ }^{15,16}$ Electrical conductivity (EC) of water is a direct function of its total dissolved salts. ${ }^{17}$ Hence it is an index to represent the total concentration of soluble salts in water. ${ }^{18}$ Therefore, this study aimed at analyzing physiochemical/sensitivity parameter present in the water based on pH, Salinity, EC, TDS, TS, and TSS across Yewa River and part of Badagry Creek and to show how they correlate to one another.

\section{Study area}

The study area is Yewa River and Part of Badagry Creek. The study stretch from Yewa River to Part of Badagry Creek precisely from Badagry to Ajido (Right) and the boundary between Nigeria and Benin Republic (Left). The Badagry creek and Yewa River is a major sea transportation route for transporting Badagry and Yewa residents and their goods from the ancient city of Badagry and Yewa to the other coastal areas of Lagos as Lagos Island, Apapa and Epe. For this reason, the navigable passage is often very busy with several private and commercial vessels plying the route. Yewa River is a stream

Table I Water recommendation and use (class H - Hydrographic) in Lagos (Nigeria (general), Nigeria (Africa) with the region font code of Africa/Middle East. It is located at an elevation of 36 meters above sea level and its population amounts to 174,152 . Yewa River is a trans-boundary (international) river between the republic of Benin (source) and Nigeria and it lies approximately within Longitude $2.70^{\circ} \mathrm{mE}$ and $3.00^{\circ} \mathrm{mE}$ of the Greenwich meridian and Latitude $6.25^{\circ} \mathrm{mN}$ and $6.75^{\circ} \mathrm{mN}$ of the equator. Badagry Creeks is located in Lagos, Lagos State, Nigeria. The Creek separate the mainland sedimentary basin from the Atlantic Coastline. It lies within Longitude $2^{\circ} 42^{\prime} \mathrm{mE}$ and $3^{\circ} 42^{\prime} \mathrm{mE}$ and stretches between Latitude $6^{\circ} 22^{\prime} \mathrm{mN}$ and $6^{\circ} 42^{\prime} \mathrm{mN}$, sharing boundary with Republic of Benin. Badagry Creek is approximately $177 \mathrm{~km}^{\circ}$ long $^{19}$ (Figure 1 ), and directly connects with Nigeria $960 \mathrm{~km}$ of coastline bordering the Atlantic Ocean in the Gulf of Guinea, a marine area of $46,500 \mathrm{~km}$ with depth of up to $50 \mathrm{~m}$ and an Exclusive Zone of $210,900 \mathrm{~km}^{2}$. There is a harbor which is constructed in the form of a channel. The water in Badagry Creek is not shallow. The Creek is important for both artisanal and commercial fisheries, and as well as transportation, recreation and domestic purposes. Also serve as means of livelihood for fishermen and women. Below show the maps of the study area by image credit ${ }^{20}$ and Google earth satellite imagery 2015 (Figure 2). There are two main methods of determining the salt content in water: The Total Dissolved Salts (or Solids) and Electrical Conductivity. Total Dissolved Salts (TDS) is measured by evaporating a known volume of water to dryness, then weighing the solid residue remaining while Electrical conductivity (EC) is measured by passing an electric current between two metal plates (electrodes) in the water sample and measuring how readily current flows (i.e. conducted) between the plates. The more dissolved salt in the water, the stronger the current flow and the higher the EC. Table 1 shows the water recommendation and use for different $\mathrm{EC}$ rates.

\begin{tabular}{|c|c|}
\hline $\boldsymbol{\mu S} / \mathbf{c m}$ & Use \\
\hline \multirow{3}{*}{$0-800$} & Good drinking water for humans (provided there is no organic pollution and not too much suspended clay material) \\
\hline & $\begin{array}{l}\text { Generally good for irrigation, though above } 300 \mu \mathrm{S} / \mathrm{cm} \text { some care must be, particularly with overhead sprinklers, which may cause leaf, } \\
\text { scorch on some salt sensitive plants. }\end{array}$ \\
\hline & Suitable for all livestock \\
\hline \multirow{3}{*}{$\begin{array}{l}800- \\
2500\end{array}$} & Can be consumed by humans, although most would prefer water in the lower half of this range if available \\
\hline & $\begin{array}{l}\text { When used for irrigation, requires special management including suitable soils, good drainage and consideration of salt tolerance of } \\
\text { plants }\end{array}$ \\
\hline & Suitable for all livestock \\
\hline \multirow{3}{*}{$\begin{array}{l}2500 \\
-10,000\end{array}$} & Not recommended for human consumption, although water up to $3000 \mu \mathrm{S} / \mathrm{cm}$ can be consumed \\
\hline & $\begin{array}{l}\text { Not normally suitable for irrigation, although water up to } 6000 \mu \mathrm{S} / \mathrm{cm} \text { can be used on very salt tolerant crops with very special } \\
\text { management techniques. Over } 6000 \mu \mathrm{S} / \mathrm{cm} \text {, occasional emergency may be possible with care }\end{array}$ \\
\hline & $\begin{array}{l}\text { When used for drinking water by poultry and pigs, the salinity should be limited to about } 6000 \mu \mathrm{S} / \mathrm{cm} \text {. Most other livestock can use } \\
\text { water up to } 10000 \mu \mathrm{S} / \mathrm{cm}\end{array}$ \\
\hline \multirow{5}{*}{$\begin{array}{l}\text { Over } \\
10,000\end{array}$} & Not suitable for human consumption or irrigation \\
\hline & $\begin{array}{l}\text { Not suitable for poultry, pigs or any lactating animals, but beef cattle can use water to } 17000 \mu \mathrm{S} / \mathrm{cm} \text { and adult sheep on dry feed can } \\
\text { tolerate } 23000 \mu \mathrm{S} / \mathrm{cm} \text {. However, it is possible that waters below these levels could contain unacceptable concentrations of particular } \\
\text { ions. Detailed chemical analysis should therefore be considered before using high salinity water for stock. }\end{array}$ \\
\hline & Water up to $50000 \mu \mathrm{S} / \mathrm{cm}$ (the salinity of the sea) can be used \\
\hline & I. To flush toilets provided corrosion in the cistern can be controlled and \\
\hline & 2. For making concrete, provided the reinforcement is well covered. \\
\hline
\end{tabular}

Source, ${ }^{21}$ 


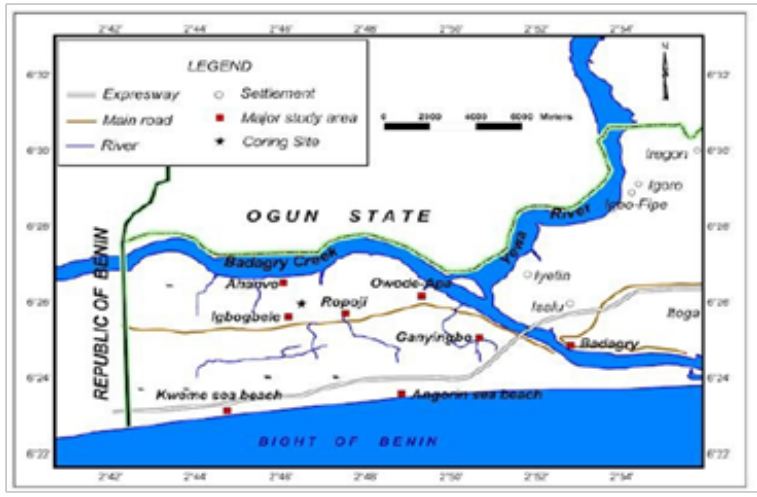

Figure I Map of Badagry Creek and Yewa River.

Source, (Image credit: 20)

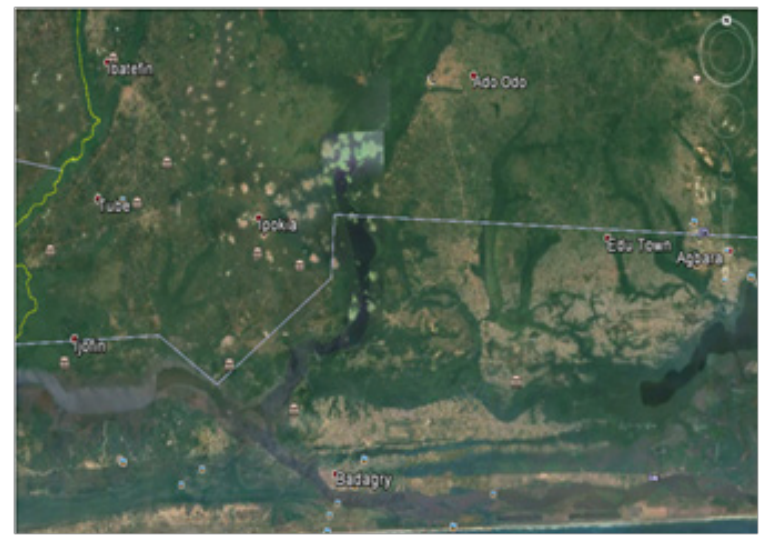

Figure 2 Google earth imagery of the study area.

\section{Materials and methods}

\section{Equipment used:}

1. Empty Bottles of Table water 30

2. Handheld GPS (Garmin) 1

3. Boat (used in movement on water) 1

\section{Methods/Procedures of sampling}

Analysis of Chemical composition and salt content in water samples make available the facts about changes that has occurred in groundwater systems which will help in understanding the water conditions and causes of its changes. For this study, water salinity was done by collecting a water sample from different point along Yewa River and Badagry Creek. The coordinates $\mathrm{x}$, $\mathrm{y}$ of each sample point was determined with handheld GPS as at the time the sample is taking. Fifteen (15) samples along Yewa River and Fifteen (15) samples were taken along Badagry Creek, all to a total of twenty four (30) samples from both the River and the Creek drawn from midstream at 0 to 10 $\mathrm{cm}$ depth below the surface of the water. The water sample collected were tightly sealed with cover bottle as quick as possible to avoid exposure to air and took to the laboratory for immediately analysis for some sensitive parameters like $\mathrm{pH}$, electrical conductivity (EC) and total dissolved solids (TDS), total suspended solid (TSS) and total solid (TS) respectively. The sampling period was during the dry season (November 18th, 2015). The techniques of water sampling come after as defined by. ${ }^{22,23}$ The chemical analyses were conducted at the Lagos University Teaching Hospital (LUTH). The significance of the correlation between parameters was calculated for Yewa River and part of Badagry Creek as well as correlation that exist between the both using the critical value of Pearson's $r$ for a two-tailed test as follows; The degree of freedom for both the river and the Creek $=$ total sampled -2 , since the total sample is fifteen (15) for each, then the degree of freedom (d.f) $=15-2=13$ and from the Pearson ' $r$ ' statistical table, the degree of freedom for 13 at $1 \%(0.01), 5 \%$ $(0.05)$ and $10 \%(0.1)$ were $(0.641,0.541$ and 0.441$)$ and was used to compare the result of the ' $\mathrm{r}$ ' statistics from the correlation coefficient matrix table which was used to show the level of significance between parameters. Table 2 shows the sampled locations/name for both the river and the Creek. Table 3 below shows the $\mathrm{x}, \mathrm{y}$ coordinates of each sample point with their locations.

Table 2 Shows the sampled area across Yewa River and part of Badagry Creek

\begin{tabular}{|c|c|}
\hline Sampled location across yewa river & Sample \\
\hline Agbonyedo Agbajedo & I \\
\hline Ere & 2 \\
\hline Itire Itere & 3 \\
\hline Seje & 4 \\
\hline Ipokia & 5 \\
\hline Ibawe Kararemunao & 6 \\
\hline Itohun & 7 \\
\hline Iyafin Isalu & 8 \\
\hline Between Itohun and lyafin Isalu & 9 \\
\hline Igbo - Fipe & 10 \\
\hline Igoro & 11 \\
\hline Iregon & 12 \\
\hline Bamin Gbobamingbe & 13 \\
\hline Odan Popo Afami & 14 \\
\hline Onfo & 15 \\
\hline Sampled location of part of badagry creek & Sample \\
\hline Badagri Badagry & I \\
\hline Towpo Topo & 2 \\
\hline Akarakumo & 3 \\
\hline Between Akarakumo and Ajido & 4 \\
\hline Ajido Wuru & 5 \\
\hline Ojogun & 6 \\
\hline Epe & 7 \\
\hline Appa Apa & 8 \\
\hline Between Appa Apa and Akere & 9 \\
\hline Igbaji & 10 \\
\hline Between Igbaji and Ganyingbo & 11 \\
\hline Ganyingbo & 12 \\
\hline Akere & 13 \\
\hline Shoki Soke & 14 \\
\hline Whekan & 15 \\
\hline
\end{tabular}

Source, Authors field Survey 2015 
Table 3 Coordinates of points sampled during water sampling

\begin{tabular}{|c|c|c|c|}
\hline \multicolumn{4}{|c|}{ G.p.s. locations and station names of sampled areas in yewa river } \\
\hline Sample & Location name & Easting (mE) & Northings $(\mathrm{mN})$ \\
\hline I & Agbonyedo Agbajedo & 483174.7 & 712265.4 \\
\hline 2 & Ere & $484 I I 1.8$ & 713202.4 \\
\hline 3 & Itire Itere & 484793.3 & $7|4| 82.1$ \\
\hline 4 & Seje & 485176.6 & 715204.3 \\
\hline 5 & Ipokia & 487135.9 & 715246.9 \\
\hline 6 & Ibawe Kararemunao & 488839.6 & 717035.8 \\
\hline 7 & Itohun & 488797 & 719847 \\
\hline 8 & lyafin Isalu & 487306.3 & 722402.6 \\
\hline 9 & Between Itohun and lyafin Isalu & 487774.8 & 724276.7 \\
\hline 10 & Igbo - Fipe & 489623.1 & 716101.6 \\
\hline 11 & Igoro & 489938.3 & 717520 \\
\hline 12 & Iregon & 489938.3 & 718938.5 \\
\hline 13 & Bamin Gbobamingbe & 492672.6 & 720417.6 \\
\hline 14 & Odan Popo Afami & 483911.8 & 717447.4 \\
\hline 15 & Onfo & 483851.8 & 723747.9 \\
\hline \multicolumn{4}{|c|}{ G.P.S. Locations and Station Names of Sampled Areas of Part of Badagry Creek } \\
\hline Sample & Location Name & Easting (mE) & Northings (mN) \\
\hline I & BadagriBadagry & 468735.6 & 713670.9 \\
\hline 2 & Towpo Topo & 471163.4 & 713032 \\
\hline 3 & Akarakumo & 473846.8 & 712776.5 \\
\hline 4 & Between Akarakumo and Ajido & 476530.1 & 713287.6 \\
\hline 5 & Ajido Wuru & 479724.6 & 713245 \\
\hline 6 & Ojogun & 482109.9 & 711413.5 \\
\hline 7 & Epe & 485261.8 & 709496.8 \\
\hline 8 & Appa Apa & 485964.2 & 709197.6 \\
\hline 9 & Between Appa Apa and Akere & 489095.2 & 708261.6 \\
\hline 10 & lgbaji & 492417.5 & 708261.6 \\
\hline II & Between Igbaji and Ganyingbo & 496165.7 & 708474.6 \\
\hline 12 & Ganyingbo & 499212.7 & 708345.6 \\
\hline 13 & Akere & 502152.1 & 708090 \\
\hline 14 & Shoki Soke & 504495.1 & 708729 \\
\hline 15 & Whekan & 508289.4 & 708601.2 \\
\hline
\end{tabular}

Source, Authors field Survey 2015

\section{Methods used for chemical analyses}

Salinity is not measured directly for this study but is derived from the conductivity measurement, ${ }^{24}$ This is known as practical salinity. Salinity measurements based on conductivity values are unitless, but are often followed by the notation of practical salinity units (psu). ${ }^{25}$ Digital $\mathrm{pH}$ and digital conductivity meter were used to determine the $\mathrm{pH}$ and electrical conductivity (EC) values. ${ }^{26}$ Residual sodium carbonate (RSC) and adjusted residuals sodium were calculated using standard equation procedures. Total dissolved solids (TDSs) were estimated by weighing the solid residue obtained by the evaporation of a measured volume of water samples to dryness. ${ }^{27} \mathrm{TSS}$ were measured for this study by filtering a water sample, dried, and weighed. This method is the most accurate technique for measuring total suspended solids, however it is also more difficult and time-consuming. ${ }^{28}$ The amount of solids present in a known volume of sample was weighed to determine the Total Solid. 


\section{Statistical analysis}

The statistical analysis was done using EVIEWS statistics software package (9.0 version). All sampled data were tested for correlation analysis to determine associations among various parameters measured for Yewa River, part of Badagry Creek and between both the river and the Creek. The Pearson ' $r$ ' statistics analysis showed coefficient of their correlation and their significance. Correlation coefficient is a common tool used to assess the relationship between two variables and how well one predicts the other. ${ }^{29}$

\section{Results}

The result presented here was as a result of the test carried out from the Laboratory as well as the Pearson correlation coefficient analysis. The mean, minimum and maximum values obtained for the estimates of the Laboratory test for $\mathrm{pH}$ are 5.87, 5.35, and 6.21 across Yewa and 4.72, 3.8, and 5.8 across Badagry Creek, for Salinity are $(0.499,0.34$, and 0.65$)$ psu across Yewa and $(0.46,0.28$ and 0.29$)$ psu across Badagry Creek, for EC are $(970.40,520$, and 1270) $\mu \mathrm{s} /$ $\mathrm{cm}$ across Yewa River and $(961,678$, and 1574$) \mu \mathrm{s} / \mathrm{cm}$ across part of Badagry Creek, for TDS are (485.20, 260, and 635)mg/l across Yewa River and $(480.5,339$, and 787)mg/l across Badagry Creek, for TS are (955.60, 920, and 1115)mg/l across Yewa River and (982.62, 625, and 1896)mg/l across part of Badagry Creek and TSS are (470.40, 340.5, and 815)mg/l (Table 4). $\mathrm{pH}$ value ranged from 5.35 and 6.21 across Yewa River and 3.8 to 5.8 across Badagry Creek, Salinity value were between 0.65 and $0.34 \%$ across Yewa River and (0.28 and 0.79$) \%$ across Badagry Creek, EC value ranged from (926 and 1270) $\mu \mathrm{s} / \mathrm{cm}$ across Yewa River and (678 and 1574) $\mu \mathrm{s} / \mathrm{cm}$ across Badagry Creek, TDS value were between (260 and 635)mg/l across Yewa River and (339 and 787)mg/l across Badagry Creek, TS value ranged between (876 and 1115)mg/l across Yewa River and (625 and 1896)mg/l across Badagry Creek, TSS value ranged between (340.5 and 815)mg/l across Yewa River and (153 and 1109)mg/l across Badagry Creek (Table 4). The percentage of $\mathrm{pH}$ ranged between (6-7)\%, Salinity were between
(5-9)\%, EC (3-9)\%, TDS (3-9)\%, TS (6-8)\% and TSS (5-12)\% across Yewa River and percentage of $\mathrm{pH}$ ranged between $(5-8) \%$, Salinity $(4-11) \%$, EC (5-11)\%, TDS (5-11)\%, TS (4-13)\% and TSS $(2-15) \%$. Table 5-7 showed the result of the Pearson correlation coefficient analysis carried out on all samples. $\mathrm{pH}$ showed a positive and strong significant relationship with EC $(\mathrm{r}=.543)$, Salinity with EC and $\mathrm{pH}(\mathrm{r}$ $=.513, .826) \mathrm{TDS}$ with $\mathrm{EC}$ and $\mathrm{pH}$, and Salinity $(\mathrm{r}=1.000, .543$ and $.513)$ TS showed weak relationship with EC, $\mathrm{pH}$, Salinity and TDS $(\mathrm{r}=.054, .037, .086$ and .054$)$ and not significant, TSS with positive and strong significant relationship with TS $(r=.671)$ and negative with no relationship with EC, $\mathrm{pH}$, Salinity and TDS $(\mathrm{r}=-.704,-.376$, -.320 and -.704) across Yewa River and across Badagry Creek, $\mathrm{pH}$ showed a positive and no significant correlation with $\mathrm{EC}(\mathrm{r}=.050)$, Salinity with positive and strong correlation with EC $(\mathrm{r}=.796)$ and $\mathrm{pH}(\mathrm{r}=.218)$ which showed a weak correlation, Salinity showed positive and strong relationship with EC $(\mathrm{r}=.796)$ and positive but weak correlation with $\mathrm{Ph}(\mathrm{r}=.218)$, TDS showed positive and strong relationship with EC and Salinity $(\mathrm{r}=.999, .796)$ and with positive but weak correlation with $\mathrm{pH}(\mathrm{r}=.050)$, TS showed a positive and strong correlation with EC, Salinity and TDS ( $r=.708, .575$ and .708) and positive and weak correlation with $\mathrm{pH}$. TSS showed a positive and strong correlation with TS $(r=.911)$ and weak correlation with EC, pH, Salinity and TDS across part of Badagry Creek. Also, TS in Badagry showed positive and strong correlation with TS in Yewa ( $\mathrm{r}$ $=.530)($ Table $5-7)$. (Figure 3) presents the percentage $(\%)$ for each sample, (Figure 4) presents trend across both the River and Creek, (Figure 5) presents parameter variation to a total in 3D across category for both the River and Creek, Figure 6 shows Bar graph of Yewa and part of Badagry Creek and (Figure 7) (Figure 8) presents the quantiles scatter plot for both the River and the Creek which showed how the correlation relates to the strength of the linear association. Therefore, it can be perceived from the scatter plot that the points are reasonably closely scattered about an underlying straight lines as opposed to a curves, so it can be said that there is a strong linear relationship between the parameter. The scattered plot showed that as the quantiles of normal increases so the quantiles of the parameter increases.

Table 4 Salinity variation across yewa and part of badagry creek and their concentration in percentages (\%)

\begin{tabular}{|c|c|c|c|c|c|c|c|c|}
\hline \multicolumn{9}{|c|}{ Salinity variation across yewa river } \\
\hline $\begin{array}{l}\text { Sample location/station } \\
\text { name }\end{array}$ & Sample & $\mathbf{P h}$ & Salinity(\%०) & $\begin{array}{l}\text { Conductivity } \\
\text { ec(as/cm) }\end{array}$ & $(\mathrm{dS} / \mathrm{m})$ & $\begin{array}{l}\text { Tds } \\
(\mathrm{mg} / \mathrm{l})\end{array}$ & $\begin{array}{l}\text { Ts } \\
(\mathrm{mg} / \mathrm{l})\end{array}$ & $\begin{array}{l}\text { Tss } \\
(\mathrm{mg} / \mathrm{l})\end{array}$ \\
\hline Agbonyedo Agbajedo & 1 & $6.2(7 \%)$ & $0.65(9 \%)$ & $926(6 \%)$ & 0.926 & $463(6 \%)$ & $965(7 \%)$ & $502(7 \%)$ \\
\hline Ere & 2 & $6.1(7 \%)$ & $0.54(7 \%)$ & $1270(9 \%)$ & 1.27 & $635(9 \%)$ & 1115 (8\%) & $480(7 \%)$ \\
\hline Itire Itere & 3 & $5.5(6 \%)$ & $0.38(5 \%)$ & $520(3 \%)$ & 0.52 & $260(3 \%)$ & $1075(8 \%)$ & $815(12 \%)$ \\
\hline Seje & 4 & $5.7(6 \%)$ & $0.46(6 \%)$ & $982(7 \%)$ & 0.982 & $491(7 \%)$ & $946(7 \%)$ & $455(6 \%)$ \\
\hline Ipokia & 5 & $5.8(7 \%)$ & $0.48(6 \%)$ & $974(7 \%)$ & 0.974 & $487(7 \%)$ & $920(6)$ & $433(6 \%)$ \\
\hline Ibawe Kararemunao & 6 & $6.21(7 \%)$ & $0.62(8 \%)$ & $1123(8 \%)$ & 1.123 & $56 \mid .5(8 \%)$ & $1033(7 \%)$ & $471.5(7 \%)$ \\
\hline Itohun & 7 & $5.64(6 \%)$ & $0.45(6 \%)$ & $962(6 \%)$ & 0.962 & 481 (6\%) & $1072(8 \%)$ & 591 (8\%) \\
\hline lyafin Isalu & 8 & 5.35 (6\%) & 0.34 (5\%) & 938 (6\%) & 0.938 & 469 (6\%) & 885 (6\%) & 416 (6\%) \\
\hline $\begin{array}{l}\text { Between Itohun and lyafin } \\
\text { Isalu }\end{array}$ & 9 & 6.18 (7\%) & 0.57 (8\%) & II 65 (8\%) & 1.165 & 582.5 (8\%) & 923 (7\%) & 340.5 (5\%) \\
\hline Igbo-Fipe & 10 & 6.15 (7\%) & 0.47 (6\%) & 856 (6\%) & 0.856 & 428 (6\%) & 876 (6\%) & 448 (6\%) \\
\hline Igoro & 11 & $5.90(7 \%)$ & $0.52(7 \%)$ & 978 (7\%) & 0.978 & 489 (7\%) & $889(6 \%)$ & 400 (6\%) \\
\hline Iregon & 12 & $5.60(6 \%)$ & $0.5 \mathrm{I}(7 \%)$ & 899 (6\%) & 0.899 & $449.5(6 \%)$ & 906 (6\%) & $456.5(6 \%)$ \\
\hline
\end{tabular}


Table Continued....

\begin{tabular}{|c|c|c|c|c|c|c|c|c|c|}
\hline \multicolumn{10}{|c|}{ Salinity variation across yewa river } \\
\hline $\begin{array}{l}\text { Sample location/station } \\
\text { name }\end{array}$ & Sample & $\mathbf{P h}$ & Salinity(\%०) & \multicolumn{2}{|c|}{$\begin{array}{l}\text { Conductivity } \\
\text { ec(as/cm) }\end{array}$} & (dS/m) & $\begin{array}{l}\text { Tds } \\
(\mathrm{mg} / \mathrm{l})\end{array}$ & $\begin{array}{l}\text { Ts } \\
(\mathrm{mg} / \mathrm{l})\end{array}$ & $\begin{array}{l}\text { Tss } \\
(\mathrm{mg} / \mathrm{l})\end{array}$ \\
\hline Odan Popo Afami & 14 & $5.84(7 \%)$ & $0.5 \mathrm{I}(7 \%)$ & \multicolumn{2}{|l|}{988 (7\%) } & 0.988 & 494 (7\%) & $899(6 \%)$ & $405(6 \%)$ \\
\hline \multirow[t]{4}{*}{ Onfo } & 15 & $5.96(7 \%)$ & $0.55(7 \%)$ & \multicolumn{2}{|l|}{$969(7 \%)$} & 0.969 & 484.5 (7\%) & 918 (6\%) & $433.5(6 \%)$ \\
\hline & Mean & 5.87 & 0.499 & \multicolumn{2}{|l|}{970.4} & 0.968 & 485.2 & 955.6 & 470.4 \\
\hline & Minimum & 5.35 & 0.34 & \multicolumn{2}{|l|}{520} & 0.52 & 260 & 920 & 340.5 \\
\hline & Maximum & 6.21 & 0.65 & \multicolumn{2}{|l|}{1270} & 1.27 & 635 & 1115 & 815 \\
\hline \multicolumn{10}{|c|}{$\begin{array}{l}\text { Salinity Variation of Part of Badagry } \\
\text { Creek }\end{array}$} \\
\hline BadagriBadagry & 1 & $4.6(7 \%)$ & $0.33(5 \%)$ & 691 (5\%) & 0.691 & \multicolumn{2}{|l|}{$345.5(5 \%)$} & $1030(7 \%)$ & $685(9 \%)$ \\
\hline Towpo Topo & 2 & $4.8(7 \%)$ & 0.79 (I I\%) & I574 (I I \%) & $\mathrm{I} .574$ & \multicolumn{2}{|l|}{787 (II\%) } & 1896 (I3\%) & $\begin{array}{l}1109 \\
(15 \%)\end{array}$ \\
\hline Akarakumo & 3 & $4.3(6 \%)$ & $0.52(8 \%)$ & 1061 (7\%) & $\mathrm{I} .06 \mathrm{I}$ & \multicolumn{2}{|l|}{530.5 (7\%) } & $1057.5(7 \%)$ & $527(7 \%)$ \\
\hline $\begin{array}{l}\text { Between Akarakumo and } \\
\text { Ajido }\end{array}$ & 4 & $5.7(8 \%)$ & $0.48(7 \%)$ & 967 (7\%) & 0.967 & \multicolumn{2}{|l|}{$483.5(7 \%)$} & I I 03.8 (7\%) & $620.3(8 \%)$ \\
\hline Ajido Wuru & 5 & $4.6(6 \%)$ & $0.33(5 \%)$ & 687 (5\%) & 0.687 & \multicolumn{2}{|l|}{$343.5(5 \%)$} & $837.3(6 \%)$ & $493.8(7 \%)$ \\
\hline Ojogun & 6 & $4.5(6 \%)$ & $0.32(5 \%)$ & $681(5 \%)$ & $0.68 I$ & \multicolumn{2}{|l|}{340.5 (5\%) } & $827.2(6 \%)$ & 486.7 (7\%) \\
\hline Epe & 7 & $5.4(8 \%)$ & $0.39(6 \%)$ & 947 (6\%) & 0.947 & \multicolumn{2}{|l|}{$473.5(6 \%)$} & 847 (6\%) & $373.5(5 \%)$ \\
\hline Appa Apa & 8 & $4.7(7 \%)$ & $0.68(10 \%)$ & I398 (I0\%) & 1.398 & \multicolumn{2}{|l|}{$699(10 \%)$} & 1058 (7\%) & $359(5 \%)$ \\
\hline $\begin{array}{l}\text { Between Appa Apa and } \\
\text { Akere }\end{array}$ & 9 & $5.6(8 \%)$ & $0.44(6 \%)$ & $886(6 \%)$ & 0.886 & \multicolumn{2}{|l|}{$443(6 \%)$} & 1011 (7\%) & $568(8 \%)$ \\
\hline Igbaji & 10 & $3.9(6 \%)$ & $0.28(4 \%)$ & $986(7 \%)$ & 0.986 & \multicolumn{2}{|l|}{493 (7\%) } & $646(4 \%)$ & $153(2 \%)$ \\
\hline $\begin{array}{l}\text { Between Igbaji and } \\
\text { Ganyingbo }\end{array}$ & 11 & $4.2(6 \%)$ & $0.5 \mathrm{I}(7 \%)$ & $102 \mid(7 \%)$ & 1.021 & \multicolumn{2}{|l|}{$510.5(7 \%)$} & 1022.3 (7\%) & $511.8(7 \%)$ \\
\hline Ganyingbo & 12 & $4.5(6 \%)$ & $0.31(4 \%)$ & $678(5 \%)$ & 0.678 & \multicolumn{2}{|l|}{$339(5 \%)$} & $821.2(6 \%)$ & $482.2(6 \%)$ \\
\hline Akere & 13 & $5.8(8 \%)$ & $0.52(8 \%)$ & $984(7 \%)$ & 0.984 & \multicolumn{2}{|l|}{492 (7\%) } & 935 (6\%) & $443(6 \%)$ \\
\hline \multirow[t]{4}{*}{ Whekan } & 15 & $4.4(6 \%)$ & $0.67(10 \%)$ & $892(6 \%)$ & 0.892 & \multicolumn{2}{|l|}{$446(6 \%)$} & 625 (4\%) & $179(2 \%)$ \\
\hline & Mean & 4.72 & 0.46 & 961 & 0.961 & \multicolumn{2}{|l|}{480.5} & 982.62 & 496.25 \\
\hline & Minimum & 3.8 & 0.28 & 678 & 0.678 & \multicolumn{2}{|l|}{339} & 625 & 153 \\
\hline & Maximum & 5.8 & 0.79 & 1574 & $\mathrm{I} .574$ & \multicolumn{2}{|l|}{787} & 1896 & 1109 \\
\hline \multicolumn{2}{|l|}{ WHO standard } & $6.5-6.8$ & & \multicolumn{2}{|l|}{1000} & \multicolumn{3}{|l|}{500} & \\
\hline
\end{tabular}

Source, Authors computation

Note, To convert from $\mu \mathrm{S} / \mathrm{cm}$ to $\mathrm{dS} / \mathrm{m}$, divide by 1000 . To approximately convert from $\mu \mathrm{S} / \mathrm{cm}$ to $\mathrm{mg} / \mathrm{l}$, multiply by 0.5

Table 5 Pearson Correlation matrix of parameter studied for Yewa

\begin{tabular}{|c|c|c|c|c|c|c|}
\hline Parameters & Conductivity ( $\mu \mathrm{s} / \mathrm{cm})$ & ph & Salinity(\%) & Tds (mg/l) & $\mathrm{Ts}(\mathrm{mg} / \mathrm{l})$ & Tss (mg/l) \\
\hline Conductivity ec & 1 & & & & & \\
\hline ph & $0.543 * *$ & 1 & & & & \\
\hline Salinity & $0.513 * * *$ & $0.826 *$ & I & & & \\
\hline Tds & $1.000 *$ & $0.543 * *$ & $0.513^{* * *}$ & I & & \\
\hline Ts & 0.054 & 0.037 & 0.086 & 0.054 & 1 & \\
\hline Tss & -0.704 & -0.376 & -0.32 & -0.704 & $0.67 I *$ & I \\
\hline
\end{tabular}

*, ** and *** represent $1 \%(0.01), 5 \%(0.05)$ and I0\% (0.I) levels of significance respectively for 2 tailed Test

Source, Authors Computation

Citation: Adewuyi GK, Badejo OT, Idowu FF, et al.Analysis of physico-chemical parameters: an empirical study of yewa river ogun and part of badagry creek lagos, Southwest Nigeria. Int J Hydro. 20I7; I (7):202-2II. DOI: 10.15406/ijh.2017.01.00036 
Table 6 Pearson Correlation matrix of parameter studied for part of Badagry Creek

\begin{tabular}{lllllll}
\hline Parameters & Conductivity $(\mu \mathrm{s} / \mathrm{cm})$ & ph & Salinity $(\mathrm{psu})$ & Tds $(\mathbf{m g} / \mathbf{l})$ & Ts $(\mathbf{m g} / \mathbf{l})$ & Tss $(\mathbf{m g} / \mathbf{l})$ \\
\hline Conductivity ec & $\mathrm{I}$ & & & & & \\
ph & 0.05 & $\mathrm{I}$ & & & \\
Salinity & $0.796^{*}$ & 0.218 & $\mathrm{I}$ & & \\
Tds & $0.999^{*}$ & 0.05 & $0.796^{*}$ & $\mathrm{I}$ & & \\
Ts & $0.708^{*}$ & 0.176 & $0.575^{*}$ & $0.708^{*}$ & $\mathrm{I}$ & \\
Tss & 0.362 & 0.245 & 0.331 & 0.362 & $0.91 I^{*}$ & $\mathrm{I}$ \\
\hline
\end{tabular}

*represent I\% (0.0I) level of significance for 2 tailed test

Source, Authors Computation

Table 7 Pearson Correlation matrix of the same parameter between Yewa River and Part of Badagry Creek

\begin{tabular}{|c|c|c|c|c|c|c|c|c|c|c|c|c|}
\hline Parameters & $\begin{array}{l}\text { Ec } \\
(Y)\end{array}$ & $\begin{array}{l}\text { Ec } \\
\text { (B) }\end{array}$ & ph(B) & $\operatorname{ph}(Y)$ & Salinity(B) & $\begin{array}{l}\text { Salinity } \\
\text { (Y) }\end{array}$ & $\begin{array}{l}\text { Tds } \\
(\mathbf{Y})\end{array}$ & $\begin{array}{l}\text { Tds } \\
\text { (B) }\end{array}$ & $\mathbf{T s}(\mathbf{Y})$ & $\begin{array}{l}\text { Ts } \\
\text { (B) }\end{array}$ & $\begin{array}{l}\text { Tss } \\
\text { (Y) }\end{array}$ & $\begin{array}{l}\text { Tss } \\
\text { (B) }\end{array}$ \\
\hline Ec $(Y)$ & 1 & & & & & & & & & & & \\
\hline Ec (B) & 0.167 & I & & & & & & & & & & \\
\hline $\mathrm{ph}(\mathrm{B})$ & 0.339 & 0.05 & I & & & & & & & & & \\
\hline $\mathrm{ph}(\mathrm{Y})$ & 0.543 & -0.238 & -0.044 & I & & & & & & & & \\
\hline Salinity (B) & 0.211 & 0.796 & 0.218 & -0.196 & I & & & & & & & \\
\hline Salinity (Y) & 0.512 & -0.471 & -0.103 & 0.826 & -0.282 & I & & & & & & \\
\hline Tds (Y) & 0.999 & 0.167 & 0.339 & 0.543 & 0.211 & 0.512 & I & & & & & \\
\hline $\mathrm{Tds}(\mathrm{B})$ & 0.167 & 0.999 & 0.05 & -0.238 & 0.796 & $-0.47 \mid$ & 0.167 & I & & & & \\
\hline Ts $(Y)$ & 0.054 & 0.268 & 0.172 & 0.037 & 0.263 & 0.085 & 0.054 & 0.268 & I & & & \\
\hline Tss (Y) & -0.704 & 0.067 & -0.129 & -0.376 & 0.03 & -0.32 & -0.704 & 0.067 & 0.671 & 0.079 & I & \\
\hline Tss (B) & 0.429 & 0.362 & 0.245 & 0.199 & 0.331 & 0.287 & 0.429 & 0.362 & 0.565 & 0.911 & 0.083 & I \\
\hline
\end{tabular}

*represents $5 \%$ (0.05) level of significance for 2 tailed test;

Y,Yewa; B, Badagry

Source, Authors Computation

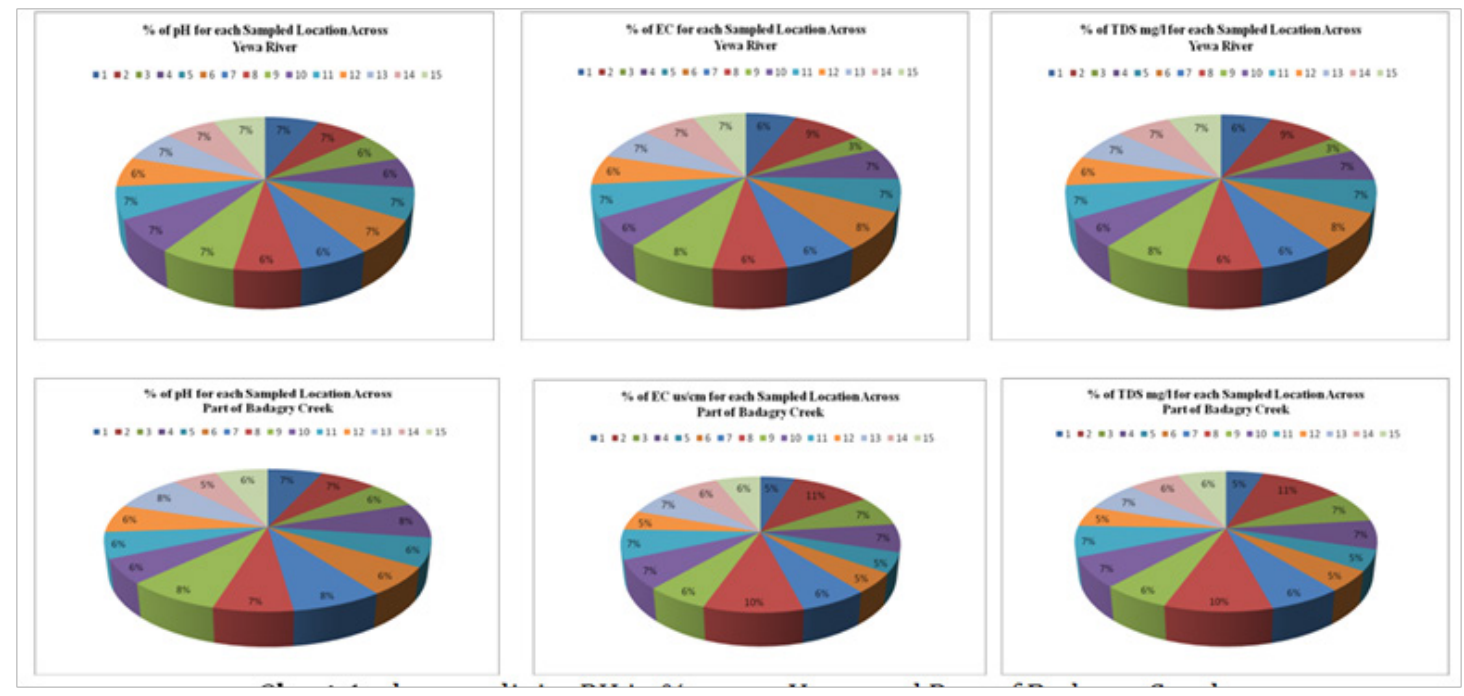

Figure 3 Shows salinity PH in \% across Yewa and Part of Badagry Creek.

Citation: Adewuyi GK, Badejo OT, Idowu FF, et al.Analysis of physico-chemical parameters: an empirical study of yewa river ogun and part of badagry creek lagos, Southwest Nigeria. Int J Hydro. 2017; I (7):202-2I I. DOI: I0.I5406/ijh.20I7.01.00036 

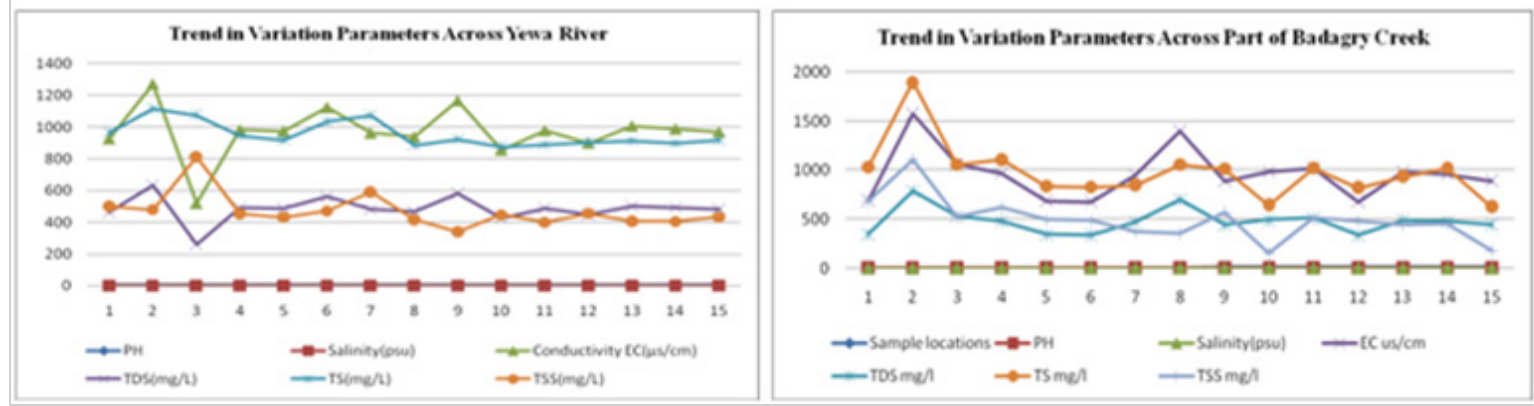

Figure 4 Shows Trend in variation parameters across Yewa River and Badagry Creek.
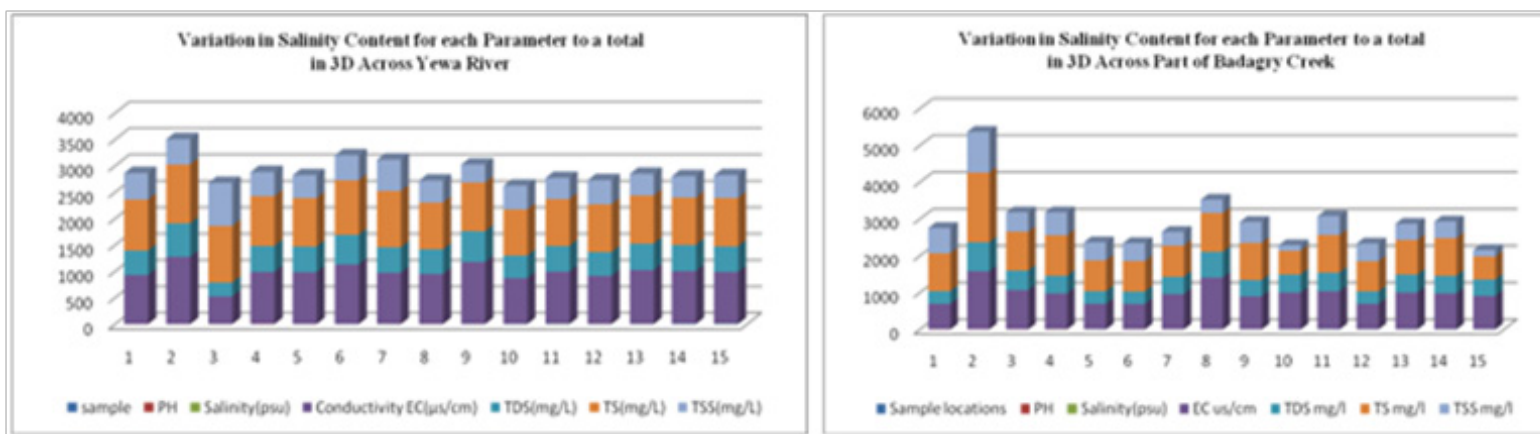

Figure 5 Shows parameter variation of a total across in 3D Across Yewa River and Badagry Creek.
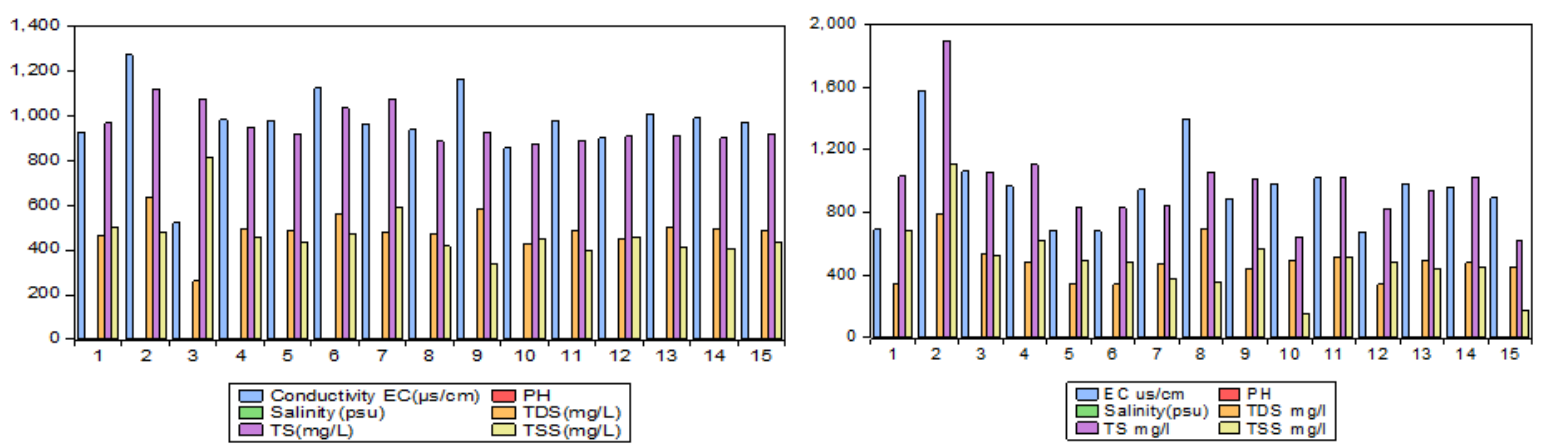

Figure 6 Bar graph showing Yewa and Badagry Creek.
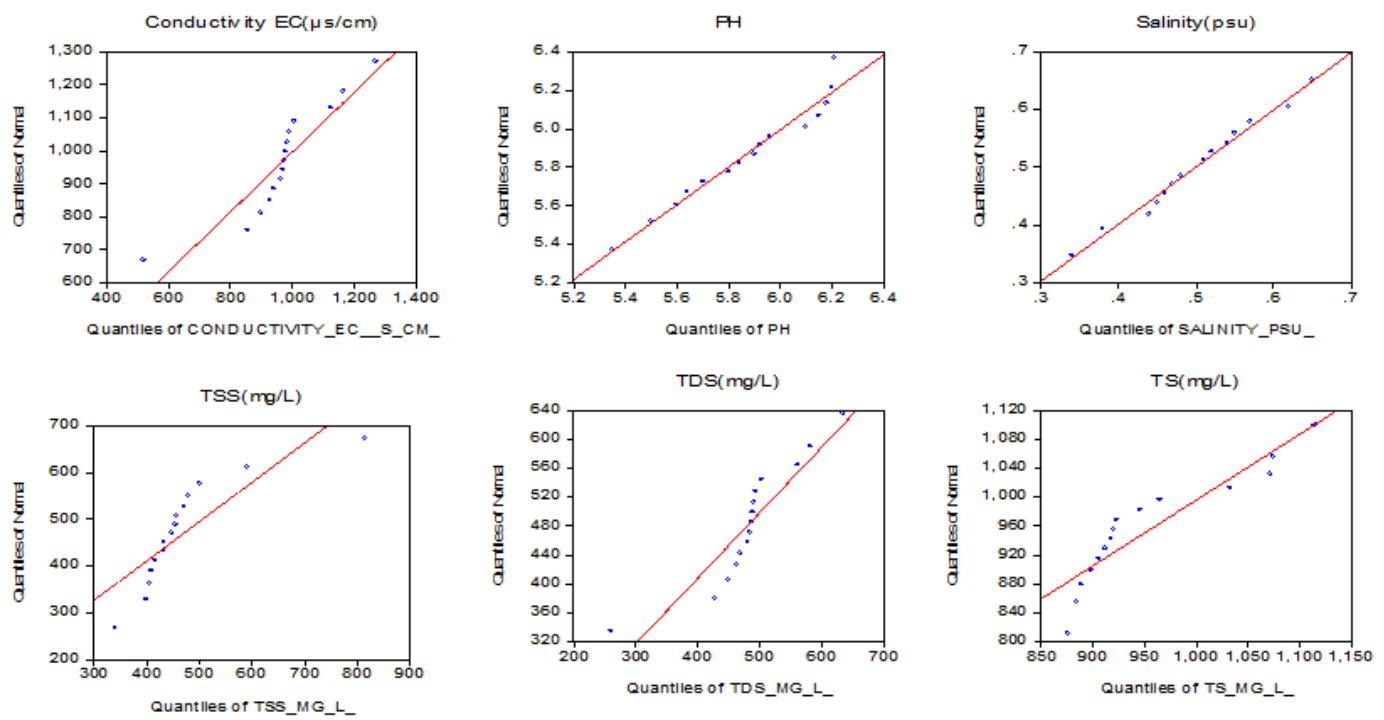

Figure 7 Shows Quantiles scatter Plot of parameter variation across Yewa River.

Citation: Adewuyi GK, Badejo OT, Idowu FF, et al.Analysis of physico-chemical parameters: an empirical study of yewa river ogun and part of badagry creek lagos, Southwest Nigeria. Int J Hydro. 20I7; I (7):202-2II. DOI: 10.15406/ijh.2017.01.00036 

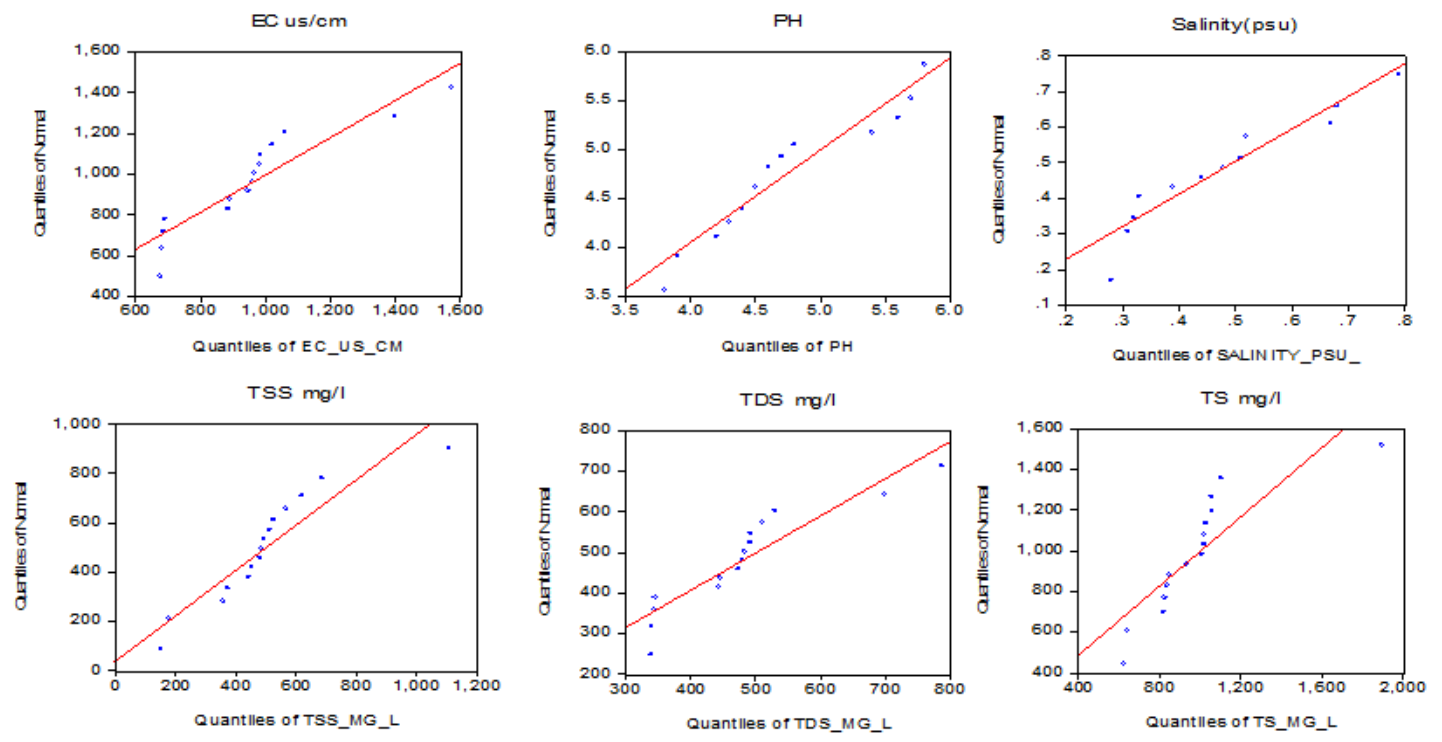

Figure 8 Shows Quantile scatter plot of parameter variation across Badagry Creek.

\section{Discussion of results}

The physical and chemical analysis on water samples across Yewa Rivera and Part of Badagry Creek has been assessed based on $\mathrm{pH}$, Salinity, EC, TDS, TS and TSS. Moreover, the average $\mathrm{pH}$ of 6.21 and 5.8 were recorded across Yewa River and part of Badagry Creek which are below WHO Standard limit of $6.5-6.8$ and this is compatible with results obtained by ${ }^{30}$ and usually indicate good water quality and this range is typical of most drainage basins of the world. ${ }^{31}$ It can then be said that Yewa River and Badagry Creek is a source of portable drinking water. It also shows that the impact of salt intrusion from the Atlantic Ocean into the Lagoon is minimum at the Yewa River and as well as Badagry creek. Only on Three (4) sampling points 2, 6, 9 and 13 with high EC (1270, 1123, 1165 and 1006) $\mu \mathrm{s} / \mathrm{cm}$ across Yewa River and sampling points 2, 3, 8 and 11 with EC (1574, 1061, 1398 and 1021) $\mu \mathrm{s} / \mathrm{cm}$ across Badagry Creek and the amount by which EC rises depends on increase in temperature. ${ }^{32}$ Also, with high TDS $(635,561.5,582.5$ and 503)mg/l across Yewa and (737, 530.5, 699 $510.5) \mathrm{mg} / \mathrm{l}$ across Badagry Creek and these high in TDS value can be attributed to the presence of salt and metals that occurred naturally and also can be as a result of domestic waste, water discharge and urban storm water run-off. And in second sample from the Badagry Creek, it showed high TSS value which can be attributed to various materials such as sewage and industrial waste, plant decayed etc. Constant consumption of this type of water with high TDS content can cause gastro-intestinal irritation and can also causes undesirable taste and corrosion. Also equal percentage in EC and TDS in the River as well as the Creek was as a result of EC being a direct function of it total dissolved salts (TDS) in water. ${ }^{18}$ Also, the acidic water as recorded from groundwater of the study area can cause corrosion of water pipes and can affect gastrointestinal tract when consumed which can lead to diarrhea. The closeness of the value in this study may be due to similarity in geology of Lagos and the study area which are all sedimentary and coastal in nature. Close relationship exists between groundwater quality and land use. ${ }^{33}$ The Correlation for this study showed the interrelationship that exists between parameters studied. From the results, increase in $\mathrm{pH}$ depends on increase in EC at $95 \%$ confidence level, increase in salinity depends on increase in
$\mathrm{EC}$ at $90 \%$ and $\mathrm{pH}$ at $99 \%$ confidence level and also increase in TDS depends on increase in EC at $99 \%$, pH at $95 \%$ and salinity at $90 \%$ confidence level and lastly, increase in TSS depends on increase in TS at $99 \%$ confidence level, all showed positive and strong correlation across Yewa River. Across Badagry Creek, increase in salinity content depends on increase in EC, increase in TDS depends on increase in EC and salinity, increase in TS depends on EC, Salinity and TDS and lastly, increase in TSS only depends on increase in TS all at 99\% confidence level with positive and strong correlation. Between Yewa River and Badagry Creek, increase in TS at Badagry Creek depends on increase in TS of Yewa River at only 95\% confidence level since there exists link (intra and interconnectivity) between both the river and the Creek. The trend that occurred between these parameters showed an indication that the pollutant present in the water and the parameter tested is strongly interrelated and interdependent on one another with common variable values that was observed. Thus, high correlations show that the parameters are derived from the same source. ${ }^{34}$

\section{Conclusion and recommendation}

Exploitation of resources from the water and indecent waste disposal to the water among people affect the quality of drinking water. Hence, from the study area, the mean of $\mathrm{pH}, \mathrm{EC}$ and TDS, TS and TSS values, the groundwater of Yewa River and Badagry Creek can be said to have low salt concentration and good for drinking and irrigation for crop production. All parameters analyses clearly fell below WHO international best standards for water quality. Therefore, from results of this study, the groundwater in Yewa and part of Badagry Creek studied can be regarded as being of good quality for drinking and agriculture purposes with reference to the parameters studied, however with little treatment of the water in both the River and the Creek to reduce the EC and TDS content especially in Ere, Ibawe, between Itohun and Iyafin Isalu, and Bamin Gbobamingbe area of Yewa and Towpo topo, Akarakumo, Appa Apa and between Igbaji \& Gayingbo area of Badagry The result of the correlation will help in understanding geochemistry of the study area. Hence, water consumption in the study area requires precautionary measures before drinking so as to protect human beings from diseases like typhoid 
and diseases. There is need for Lagos State water boards to carry out research to study the rate of salt intrusion from the Atlantic into the Lagos state inland water ways as a quick measure to ensuring sustainable availability of portable drinking water to the citizenry. Further studies on the River and Creek with reference to microbial and chemical analyses will give detailed information on the water quality.

\section{Acknowledgements}

The authors appreciate the effort of Surv. Babatunde Dayo and Mr. Jimoh Olalekan Abeeb of the Department of Surveying and Geoinformatics, University of Lagos Akoka for their physical support towards the success of the study.

\section{Conflict of interest}

Authors declare there is no conflict of interest in publishing article.

\section{References}

1. Shahnawaz MD, Singh KM. Groundwater quality of Piro and Jagdishpur Blocks Bhorps district, a middle gangatic plain. Intl J Pharma Qual Assur. 2009;1(1):9-10.

2. Khodapanah L, Sculaiman WNA, Khodapanah N. Groundwater quality assessment for different purposes in Eshtehard distric, Tehran, Iran. Eur J Sci Res. 2009;36(4):543-553.

3. Oluseyi T, Olayinka K, Adeleke I. Assessment of groundwater pollution in the in the residential areas of Ewekoro and Shagamu due to cement production. Afr J Environ Sci Technol. 2011;5(10): 786-794.

4. Nahyan Al SMBZ. Keynote address. World Future Energy Summit. 2012;187(11):1-16.

5. Rim RA, Ikhifa GO, Okokoyo PA. Physico-chemical characteristics of some waters used for drinking and domestic purposes in the Niger Delta, Nigeria. Environ Monit Assess. 2007;128(1-3):475-482.

6. WHO. Guideline for Drinking Water Quality, 3rd edn.World Health Organization, UK; 2010

7. Majuru B, Mokoena MM, Jagals P, et al. Health impact of smallcommunity water supply reliability. Int $J$ Hyg Environ Health. 2011;214(2):162-166.

8. Groundwater Foundation. What is groundwater?. Groundwater Foundation, USA; 2012

9. Saeed TU, Khan D. Assessment and conservation of groundwate quality: A challenge for agriculture. Br J Applied Sci Technol. 2014;4(8):1256-1272.

10. United Nations. Millennium Development Goals. United Nations, USA; 2000 .

11. Mac Donald AM, Calow RC. Developing groundwater for secure rural water supplies in Africa. Desalination. 2009;248(1-3):546-556.

12. Leschik S, Musolff A, Krieg R, et al. Application of integral pumping tests to investigate the influence of a losing stream on groundwater quality. Hydrol Earth Syst Sci. 2009;13:1-10.

13. UNICEF. UNICEF Handbook on Water Quality. United Nations Children's Fund (UNICEF), USA; 2008. p. 1-179.

14. Al-Harbi OA, Hussain G, Khan MM, et al. Evaluation of groundwater quality and its recharge by isotopes and solute chemistry in Wad Malal, Al-Madinah Al-Munawarah, Saudi Arabia. Pakistan Journal of Biological Sciences. 2006;9:260-269.
15. Kumaraswamy N. Assessment of Water Quality Index for the Groundwater in Tumkur Taluk. Poll Res. 1999;10(1):13-20.

16. Geetha A, Palanisamy PN, Sivakumar P, et al. Orthophosphoric Acid Activated Babul Seed Carbon as an Adsorbent for the Removal of Methylene Blue. E-Journal of Chemistry. 2008;5(4):742-753.

17. Harilal CC, Hashim A, Arun PR, et al. Hydro-geochemistry of two rivers of Kerala with special reference to drinking water quality. Ecology, Environment and Conservation. 2004;10(2):187-192.

18. Purandara BK, Varadarajan N, Jayshree K. Impact of sewage on groundwater: A case study. Poll Res. 2003;22(2):189-197.

19. FAO. Fisheries Survey in the Western and Mid- Western Regions of Nigeria. FAO, Nigeria; 1969.

20. Orijemie EA. Exploitation of Aquatic Resources in Ahanve, Badagry, south-western Nigeria. Internet Archaeology. 2014;37:1-22.

21. Anderson H, Cummings D. Measuring the Salinity of Water Sustainability and Environment Landcare Note, Australian; 1999.

22. Hunt DTE, Wilson AL. The Chemical Analysis of Water - General Principles and Techniques. ( $2^{\text {nd }}$ edn), R Soc Chem Cambridge, UK; 1986;1-683.

23. American Public Health Association (APHA). Standard Methods for the Examination of Water and Waste Water, 17th edn. USA; 1989. p. 1-175.

24. Ghosh AB, Bajaj JC, Hasan R, et al. Soil and Water Testing Methods. Division of Soil Science and Agricultural Chemistry. 1983;36-45.

25. Perlman H. Sediment and Suspended Sediment. In The USGS Water Science School. USA; 2014.

26. HWR203 Arizona Water Issues (PowerPoint). The University of Arizona, USA; 2009.

27. Chopra SL, Kanwar JS. Analytical Agricultural Chemistry. Kalyan Publishers, India; 1980. p. 1-307.

28. Langland M, Cronin, T. A Summary Report of Sediment Processes in Chesapeake Bay and Watershed. US Geological Survey. 2003;1-122.

29. Bahar M, Reza MS. Hydrochemical characteristics and quality assessment of shallow groundwater in a coastal area of Southwest Bangladesh. Environ. Earth Sci. 2010;61(5):1065-1073.

30. Ahaneku IE, Adeoye PA. Impact of pit latrines on groundwater quality of Fokoslum, Ibadan, Southwestern Nigeria. Br J Applied Sci Technol. $2014 ; 4: 440-449$.

31. UNEP/GEMS. Water quality outlook. United Nations Environmental Programme (UNEP): 2007;1-16.

32. Yilmaz E, Koc C. Physically and chemically evaluation for the water quality criteria in a farm on Akcay. J Water Resour Prot. 2014;6(2):63-67.

33. Orebiyi EO, Awomeso JA, Idowu OA, et al. Assessment of Pollution hazard of shallow well water in Abeokuta and Environs, Southwest, Nigeria. Am J Environ Sci. 2010;6(1):50-56.

34. Edet A, Nganje TN, Ukpong AJ, et al. Groundwater chemistry and quality of Nigeria: A status review. Afr J Environ Sci Technol. 2011;5(13):1152-1169. 